\title{
ІНТЕРТЕКСТУАЛЬНІСТЬ У СУЧАСНОМУ РОМАНІ З РИСАМИ ІНТЕЛЕКТУАЛІЗМУ
}

\begin{abstract}
У статті розглядається проблема інтертекстуальності як провідної ознаки інтелектуальної прози на матеріалі роману-тетраедра О. Слоньовської. Експериментальний твір складається з чотирьох романів («Загублені в часі», «Інстинкт саранчі», «Знехтувані Ноєм» та «Медуза-Гортона»), містить яскраві зразки різних форм інтертекстуальності, иікаві художні прийоми та сюжетні колізіі, відрізняється нетиповістю персонажів, переосмисленням протосюжетів. Письменниця орієнтується на ерудованого читача, спроможного розпізнавати приховані вкраплення «чужих» текстів. Система авторських ремінісценцій та алюзій демонструє індивідуальну картину світу письменнииі як проєкиію колективної свідомості. Діалог між текстами різних культур формується, передусім, через використання інтерпретації міфічних образів, біблійних легенд, творів украӥнської, зарубіжної літератур та афоризмів радянської доби.

Дешифрування текстів починається з алюзійних назв романів. Авторка вдається до несподіваних паралелей із біблійними легендами та давньогрецькими міфами. Так, біблійна алюзія на історію порятунку Ноя подається в скептичному ракурсі, адже герой роману Юрій, розмірковуючи над смислом сторінок Старого Завіту, бачить себе так само «знехтуваним Ноєм», таким, який остаточно втратив надію на порятунок. У романі «Інстинкт саранчі» авторка не лише натякає, а прямо вказує, щзо ияя ї̈ назва є алюзією, яка яскраво характеризує найпримітивніші «інстинкти таких виродків», як головний герой Льончик Жбанкін.

3 метою актуалізації смислів попередньої епохи авторка використовує ремінісценції-явні і неявні відсилання до інших текстів. Особливо яскраво цие простежується у творі «Медуза-Гортона» з головною героӥнею письменницею.

Такі «запозичення чужсого тексту» дають змогу глибше осмислити ситуацію, зробити певні висновки, щзо продукуються персонажами. Так, роман О. Слоньовської «Медуза-Гортона» є дослідженням природи творчості та натхнення. Специцфікою залучення інтертексту в романі є домінування ичитат із літературної сфери та ичитат з атрибуиією для пояснення психології творчості.
\end{abstract}

Ключові слова: інтелектуальна проза, алюзія, ремінісценція, інтертекст, метамодернізм.

Nataliia LAPUSHKINA, orcid.org/0000-0001-9591-083X Candidate of Philological Sciences, Associate Professor at the Department of Ukrainian Language and Literature Donbas State Pedagogical University (Slovyansk, Donetsk region, Ukraine) lapushkina8181@ukr.net

\section{INTERTEXTUALITY IN THE MODERN NOVEL WITH FEATURES OF INTELLECTUALISM}

The article considers the problem of intertextuality as a leading feature of intellectual prose on the material of O. Slonivska's novel-tetrahedron. Experimental work consists offour novels: "Lost in Time”, "Instinct locusts", "rejected Noah" and "Medusa-Gorgon" contains bright samples of different forms of intertextuality, interesting artistic techniques and narrative conflict that are marked by idistinctive characters, rethinking formal semantic dominants protoplots. The writer focuses on the erudite reader, able to recognize hidden patches of "foreign" texts. System author's reminiscences and allusions shows literate individual world picture these as a projection of the collective consciousness. The dialogue between the texts of different cultures is formed primarily through the use of interpretation of mythical images, biblical legends, classical works of Ukrainian and foreign literature and aphorisms of the Soviet era.

Deciphering texts begins with allusive titles of novels. The author draws unexpected parallels with biblical legends and ancient Greek myths. Yes, the biblical allusion to the story of Noah's salvation is presented in a skeptical perspective, because the hero of the novel Yuri, reflecting on the meaning of the pages of the Old Testament, sees himself as "neglected Noah», one who finally lost hope of salvation. In the novel The Locust Instinct, the author not only hints, but directly points out that this name is an allusion that vividly characterizes the most primitive "instincts of such freaks" as the protagonist L. Zhbankin. 
In order to actualize the meanings of the previous era, the author uses reminiscences - explicit and implicit references to other texts. This is especially evident in the work "Medusa-Gorgon" with the main character writer.

Such "borrowing of someone else's text" enable to deeper understand the situation, to make certain conclusions that produced characters. Thus, $O$. Slonivska's novel «Medusa-Gorgon" is a study of the nature of creativity and inspiration. The specificity of the involvement of intertext in the novel is the dominance of quotations from the literary sphere and quotations with attribution to explain the psychology of creativity.

Key words: intellectual prose, allusion, reminiscence, intertext, metamodernism.

Постановка проблеми. Досі немає однозначності у трактуванні терміна «інтелектуальний роман», особливо з огляду на модифікації жанру в XXI столітті. Проте інтелектуалізм у сучасній літературі - досить поширене явище. Він дає змогу автору, зосередившись на раціональному типі образного творчого мислення, презентувати «інтелектуальний дискурс епохи через конкретно-образні і персоніфіковані його вияви» (Ганошенко, 2015: 265). Вияв інтелектуалізму в літературі може здійснюватися як на ідейному, так і на формально-змістовому рівні. Дослідники інтелектуального роману (Н. Акулова, Ю. Ганошенко, Н. Козачук, Ш. Куриленко, С. Павличко та ін.), дискутуючи із своїми попередниками, все ж сходяться в ключових ознаках інтелектуалізму в літературі: філософічність, універсальність, порівняна декларативність ідейного змісту, апеляція до розвиненого читача, послідовна робота 3 чужим словом, що передбачає різні форми його використання в тексті. Діалог ідей, який виникає в процесі апробації філософських концепцій, залучення читача до розв'язання мисленнєвих завдань, закодованих у художній формі, роблять текст цікавим для аналізу. Спільним для творів 3 рисами інтелектуалізму $є$ наявність розвиненої інтертекстуальності. Вивчаючи інтертекст твору, можемо наблизитися до розуміння внутрішньої структури тексту, відтворення підтексту шляхом декодування прихованих алюзій та цитат. Дослідженням теорії інтертекстуальності займалися Л. Біловус, 3. Мітосек, Ю. Крістева, Ж. Женетт, М. Ріффатер, Р. Барт та інші. Проте поява кожного нового твору ставить перед літературознавцями завдання розкодування його прихованих смислів та прочитання через художній текст наскрізних ідей доби, які той презентує.

Мета статті - розглянути інтертекст тетраедра О. Слоньовської як прикладу сучасного роману з рисами інтелектуалізму, виявити його культурний гіпертекст.

Виклад основного матеріалу. Інтертекстуальність як ознака тексту, за наявності якої представлений твір містить у собі посилання на інші тексти (прямі чи приховані цитати, ремінісценції, алюзії, парафрази), дає змогу не лише прочитати глибинний смисл твору, а й вивести індивідуальну картину світу письменника як проєкцію колективної свідомості. Дотичним й у ракурсі прочитання сучасних творів $\epsilon$ вислів Р. Барта: «Кожен текст $€$ інтертекстом; інші тексти присутні в ньому на різних рівнях у більш чи менш впізнаваних формах: тексти попередньої культури і тексти культури, яка оточує. Кожен текст є новим полотном, зітканим зі старих цитат» (Барт, 1989: 102-103). Причому рівень насиченості інтертекстом впливає на ширину культурного гіпертексту. Перенасиченість такими формами, яка відбулася, наприклад, у постмодерних текстах, значно ускладнювала сприйняття твору, проте відбивала абсурдність доби. У сучасній літературі насиченість прототекстом досить помірна, логічно обгрунтована та зазвичай глибоко продумана автором. Як доречно помітила Н. Коч під час дослідження особливостей інтертексту в романі Л. Костенко, «органічна трансформація «чужого» у «своє» як основна риса інтертекстуальності втілюється у творі завдяки текстовим ремінісценціям та алюзіям різного характеру, які виражають не тільки авторські, а й національні соціокультурні стереотипи комунікації, що сформовані, насамперед, завдяки їх багаторазовому відтворенню за допомогою мовних засобів в пам'яті колективу» (Коч, 2014: 211-220). Тому будь-які свідомі чи несвідомі авторські алюзії, ремінісценції чи цитати покликані репрезентувати читачу не лише описану у творі добу, а й попередні мисленнєві дискурси, які її формували.

Експериментальний роман-тетраедр О. Слоньовської, який складається 3 чотирьох творів («Загублені в часі», «Інстинкт саранчі», «Знехтувані Ноєм» та «Медуза-Горгона»), критики зараховують до інтелектуальної прози. Романи, які входять до тетраедра, містять цікаві художні прийоми та сюжетні колізії, відзначаються нетиповістю персонажів, переосмисленням формально-змістових домінант протосюжетів, широким залученням інтертексту. Використавши поширений серед метамодерних творів прийом «комбінаторної гри», авторка надала реципієнту можливість індивідуального прочитання тексту в будь-якому порядку розташування частин. Причому кожен роман із чотирьох, являючи автономне питоме ціле, одночасно стає невід'ємною частиною чітко структурованої системи. Чи не на кожній сторінці авторка 
ненав'язливо пропонує роботу для мозку читача у сферах літератури, історії, політики, філософії, міфології, психології, різних видів мистецтв, через героїню із «синдромом інтелектуалки» намагаючись пояснити секрети письменницької творчості. Проте незважаючи на потужний інформаційний потік з безліччю риторичних запитань та своєрідних інтертекстуальних діалогів, навіть складний матеріал сприймається досить легко, стає доступним завдяки специфічній манері введення міжтекстового компонента в сюжетну канву твору. Авторські інтерпретації міфологічних сюжетів та героїв, як-от народження Пегаса чи смерть Медузи-Горгони (Слоньовська, 2019: 34), не лише допомагають зрозуміти авторську позицію та ідейне спрямування твору, а й подекуди не потребують від читача звернення до першоджерел (щоб пригадати що це за образ), адже подаються в зіставленні кількох точок зору. Отже, читач має змогу уже в процесі читання перевірити свої припущення щодо розуміння смислів тих чи інших форм інтертексту. Відомо ж, що відкриття багатовимірного простору тексту далеко не завжди є тим, що «хотів сказати» автор, а більше тим, що «говорить» текст. Крім того, й сам діалогізм мовлення, конфлікт ідей у романі виражені через протистояння героїв (чи думок у голові одного героя - внутрішній діалог) свідчать про наявність інтелектуальної складової частини тексту.

Відштовхуючись від найбільш поширеної класифікації інтертекстуальних зв'язків, виведеної Ж. Женеттом у книзі «Палімпсести: Література другого ступеня» («Palimpsestes: La littérature au second degree», 1982), можемо віднайти приклади звернення Ольги Слоньовської до усіх п’яти типів взаємодії тексту: інтертекстуальність, архітекстуальність, метатекстуальність, паратекстуальність, гіпертекстуальність. Інтертекстуальність як співприсутність в одному тексті двох або більше текстів простежується у стрижневій частині тетраедру «Медузі-Горгоні», де авторка накладає власний сюжет на кілька ідейно співзвучних текстів, пропонуючи читачу «порівняти окремі колізіі роману 3 колізіями новел «Intermezzo» та «Цвіт яблуні» М. Коцюбинського чи драми В. Винниченка «Чорна Пантера і Білий Медвідь» (Слоньовська, 2019: 2). Порівнюючи себе з Медузою-Горгоною, героїня роману доходить висновку: «Я - чудовисько. Бо нічого не можу забути. Не здатна нічого стерти зі своєї пам'яті, викинути геть. Я неспроможна вирватися, вислизнути з сітки власних неправильно влаштованих мізків. Моєї збоченої психіки з тисячами сюжетів-гадюк, як на голові у Медузи-Гортони» (Слоньовська, 2019: 35). Чимось це нагадує загаль- новідоме «Я утомився. Мене втомили люди...» М. Коцюбинського. Така непряма вказівка на образні паралелі визначається дослідниками як ремінісценція. Інтертекстуальність спостерігаємо й у такій репліці з частини «Загублені в часі»: «Ганно, є така повістинка в Ольги Кобилянської, "Valse melancolsguе» називається. Прочитайте обов'язково. Якщо ви, умовно кажучи, - Марта, то я в иьому творі - амбітна художниця, самолюбка й паскуда ще та! Ось тільки доля кожного навіть у иій повісті нагородила за його ж власними заслугами... Чи я, засліплена, раптом за фата морганою не женуся?» (Слоньовська, 2018: 16). Тут алюзії використано для пояснення характеру та дій героїнь.

Паратекстуальність як відношення тексту до свого заголовка, післямови, епіграфа виявляється в яскраво алюзійних назвах романів. Незважаючи на те, що в тексті кожного 3 них можна знайти розшифровку назви, все ж ті паралелі, які проводить авторка, видаються досить несподіваними. Так, біблійна алюзія на історію порятунку Ноя подається в скептичному ракурсі, адже герой роману Юрій, розмірковуючи над смислом сторінок Старого Завіту, бачить себе так само «знехтуваним Ноєм» (Слоньовська, 2019: 215), який остаточно втратив надію на порятунок. У романі «Інстинкт саранчі» авторка не лише натякає, а прямо вказує, що ця іiі назва $є$ алюзією, яка яскраво характеризує найпримітивніші «інстинкти таких виродків» (Слоньовська, 2019: 14), як головний герой Льончик Жбанкін.

Архітекстуальність, що розуміється як жанровий зв'язок текстів, реалізується через введений О. Слоньовською експериментальний жанр тетраедр: «чотири романи, об'єднані часом і персонажами, долі яких переплелися, діткнулись одна одної чи тільки уявно пересіклися, як мимобіжні прямі» (Слоньовська, 2019:311). Героїня «МедузиГоргони» пише власне цей роман-тетраедр, який ми читаємо, ділячись із читачем секретами та муками творчості. Тобто в кожній частині знаходимо відлуння інших трьох романів, продовження розвитку подій чи новий погляд на ті ж самі події, але $з$ боку іншого героя. Така особливість жанру передбачає й гіпертекстуальність - «такий тип зв'язків, що поєднує текст із попереднім на основі «його модифікації у формі висміювання, пародії, травестії, карикатури» (Просалова, 2019: 26), адже виникає ситуація самоцитування, посилання на власні думки та образи. Пародійне, карикатурне прочитання попереднього тексту спостерігаємо в романі «Медуза-Горгона», коли через міфологію авторка осмислює витоки творчості: «Навіть із 
мертвої Медузи-Горгони, власне з тї крові, заплідненої Посейдоном, як розповідає міф, народився Пегас - крилатий кінь мистецтва. Ну й метаморфози! Переросло зло в добро? Якби ж то!» (Слоньовська, 2019: 34).

Ще один тип інтертекстуальності - метатекстуальність «привносить елемент коментування» (Просалова, 2019: 26), критичний зв'язок між текстами. Тобто у творі О. Слоньовської з'являються коментарі, навіть більше - глибокий аналіз, що стосується іншого тексту. У романі «Медуза-Горгона» в сюжетну канву вплетено сміливий критичний погляд на радянське трактування творів О. Кобилянської «Земля», П. Мирного та І. Білика «Хіба ревуть воли, як ясла повні?». Такий авторський прийом, 3 одного боку, інтелектуалізує текст, посилює рівень довіри до написаного (героїня мислить сміливо, нестереотипно), але 3 іншого - дещо звужує читацьку аудиторію.

Створення нових смислів на основі актуалізації смислів попередніх епох досягається, передусім, через алюзії, ремінісценції, та розширюється іншими прийомами. На сторінках роману-тетраедра О. Слоньовської проводяться паралелі до інших творів української та зарубіжної літератури, використовуються жанри народного фольклору, алюзії до Біблії та міфів, пропонується авторська інтерпретація творів з української літератури (як у романі «Медуза-Горгона»), пояснення теоретичних термінів (алюзія та жіноча проза в «Інстинкті саранчі», сюжет, прототип, колізія та інші в «Медузі-Горгоні»). Авторка взаємодіє 3 власним художнім текстом, як із життям, цілим художнім світом. Тому численні складні асоціації, відкриті й приховані цитати, алюзії, ремінісценції, символічний план, наведені у творах, за задумом автора об'єднують «розбитий на дзеркальні скалки» світ в єдине ціле. Через те, що «виклад теорії перестає бути однолінійним, теоретичні положення подаються у співставленні 3 життєвими ситуаціями» (Куриленко, 2015: 274), використання інтертексту не обтяжує сюжет. Створений за допомогою прийомів інтертекстуальності текст потрапляє в систему міжтекстових і позатекстових зв'язків, які $\mathrm{\epsilon}$ своєрідним кодом, що вимагає дешифрування для адекватного розуміння змісту твору.

Особливо активно використано роботу з чужим словом у романах «Медуза-Горгона» та «Загублені в часі»: алюзії та ремінісценції («правільнай дарогай ідьоте, таваріщі!» "Есересерище відкинув копита, иензура також розчинилася в тумані, «як з білих яблунь дим» (Слоньовська, 2019: 24, 200), «Жабомитодралівка у верхах, можливо, низам була малопомітною, проте вони на власній шкурі добре відчували: щзось дуже не так у данському королівстві!» (Слоньовська, 2018: 204)), асоціативні порівняння («персонажі твого ж власного твору відчайдушно боротимуться з тобою, як у скульптурі «Лаокон» сімейство жерия зі зміями» (Слоньовська, 2019: 27), прямі цитати з літературних творів, фільмів та уривки відомих пісень (наприклад, в яких В. Висоцький «маскував пісні про КДБ під пісеньки про мілічію чи доблесних слідчих і показував ставлення простого народу до цьвого кодла» (Слоньовська, 2019: 198)), українського, російського, білоруського та єврейського фольклору, в якому відбилася епоха.

Такі «запозичення чужого тексту» дають змогу глибше осмислити ситуацію, зробити певні висновки, що продукуються персонажами. Так, роман О. Слоньовської «Медуза-Горгона» $\epsilon$ дослідженням природи творчості та натхнення. Специфікою залучення інтертексту в романі $\epsilon$ домінування цитат із літературної сфери та цитат 3 атрибуцією для пояснення психології творчості. Спроба пояснити загадковість та химерність світу мистецтва авторка робить через сучасне переосмислення міфу про Медузу-Горгону та Пегаса. Фантасмагорії міфічного простору химерно комбінуються $з$ простором реальним: «У транспорті, на вулиці, в чергах до каси на вокзалі чи в магазині або буфеті я наче перетворююся в Медузу-Горгону, здатну навіки закаменувати легкий і навіть особливо леткий матеріал, тимчасово закинути його на периферію, як комп'ютер закидає файли, якими його власник довго не користується» (Слоньовська, 2019: 274). Невидимий сторонньому оку мученицький шлях від появи натхнення до народження художнього шедевру О. Слоньовська змальовує не тільки через розшифрування міфів, а й через героїв В. Винниченка та М. Коцюбинського («письменник таки здатний відсторонено спостерігати навіть за "рисочками» смерті на обличчі, наприклад, маленького Лесика, як у драмі Винниченка» (Слоньовська, 2019: 33)), згадки про страшні вчинки позбавлених натхнення митців («Кажуть, у такі моменти відомі світові митчі лізли в зашморг, вискакували через вікно з енного поверху, прикладали дуло зарядженого пістолета до власної скроні, ковтали заспокійливе смертельними дозами, калічили себе, як художник Ван Гог...» (Слоньовська, 2019: 32)), через наведені в романі медичні наукові дослідження про специфіку письменницької праці (Ян Парандовський "Алхімія слова», Чезаре Ломброзо «Геніальність $і$ божевілля») та навіть через вислови з народу («Сорока колекціонуе за прин- 
ципом: те, щзо блищить. А навіщзо? 3 тією ж метою, що моя пам'ять: нам на Тайвані й гас пригодиться!» (Слоньовська, 2019: 275)).

Висновки. Інтертекстуальність можна вважати однією з провідних рис творчості О. Слоньовської, що разом з іншими ознаками дає підстави залучати її романи до інтелектуальної прози метамодернізму, єднає 3 художньою спадщиною попередніх поколінь. За допомогою різних форм інтертексту письменниця не лише увиразнила та інтелектуалізувала мову тексту, а й окреслила основні проблеми романів: життя та виживання на зламі державних устроїв, вплив на людину зовнішніх факторів, доля і особистісний вибір, функція жінки у суспільстві, митець і творчість. Подальше спостереження над використанням інтертекстуальності в сучасних текстах і з боку автора, і з боку читача надасть ширші можливості для виявлення міжтекстових взаємодій, які збагачують твір новими смислами, допомагають розкриттю творчих задумів і сприяють виведенню загального культурного коду нації.

\section{СПИСОК ВИКОРИСТАНИХ ДЖЕРЕЛ}

1. Барт Р. Избранные работы: Семиотика. Поэтика / пер. с фр. Москва, 1989. 615 с.

2. Ганошенко Ю. А. Інтелектуальність в романі VS інтелектуальний роман: до проблеми дифініціювання жанру. Наукові записки Бердянського державного педагогічного університету. 2015. Вип. V. С. 265-271.

3. Коч Н. В. Інтертекстуальність роману Ліни Костенко «Записки українського самашедшего». Наукові записки Бердянського державного педагогічного університету. Бердянськ, 2014. Вип. III. С. 211-220.

4. Куриленко I. А. До питання про сутність та жанрові особливості українського інтелектуального роману. Наукові записки Бердянського державного педагогічного університету. 2015. Вип. V. С. 272-279.

5. Просалова В. А. Інтертекстуальний аналіз: теорія і практика. Навчальний посібник. Вінниця, 2019. 206 с.

6. Слоньовська О. Загублені в часі. Роман. Київ : Видавництво «Український пріоритет», 2018. 272 с.

7. Слоньовська О. Інстинкт саранчі. Знехтувані Ноєм. Романи. Київ : Видавництво «Український пріоритет», 2019. $264 \mathrm{c}$.

8. Слоньовська О. Медуза-Горгона. Роман. Київ : Видавництво «Український пріоритет», 2019. 312 с.

\section{REFERENCES}

1. Bart R. Izbrannyye raboty: Semiotika. Poetika. [Selected works: Semiotics. Poetics]. 1989. 615 p. [in Russian].

2. Hanoshenko Yu. A. Intelektualnist v romani VS intelektualnyi roman: do problemy dyfinitsiiuvannia zhanru. [Intelligence in the novel VS intellectual novel: to the problem of defining the genre]. Scientific notes of Berdyansk State Pedagogical University. 2015. Vyp. V. Pp. 265-271 [in Ukrainian].

3. Koch N. V. Intertekstualnist romanu Liny Kostenko "Zapysky ukrainskoho samashedsheho". [Intertextuality of Lina Kostenko's novel "Notes of the Ukrainian samashedshego"] Scientific notes of Berdyansk State Pedagogical University. 2014. Vyp. III. Pp. 211-220 [in Ukrainian].

4. Kurylenko I. A. Do pytannia pro sutnist ta zhanrovi osoblyvosti ukrainskoho intelektualnoho romanu. [On the question of the essence and genre features of the Ukrainian intellectual novel.] Scientific notes of Berdyansk State Pedagogical University. 2015. Vyp. V. Pp. 272-279 [in Ukrainian].

5. Prosalova V. Intertekstualnyi analiz: teoriia i praktyka. Navchalnyi posibnyk. [Intertextual analysis: theory and practice.] Vinnytsia, 2019. 206 p. [in Ukrainian].

6. Slonovska O. Zahubleni v chasi. Roman. [Lost in time. Novel.] Kyiv : Ukrainian Priority, 2018. 272 p. [in Ukrainian].

7. Slonovskaya O. Meduza-Gorgona [Medusa-Gorgon]. Kyiv: Ukrainian Priority. 2019. 312 p. [in Ukrainian].

8. Slonovskaya O. Instynkt saranchi. Znekhtuvani Nojem [The instinct of locusts. Neglected by Noah]. Kyiv: Ukrainian Priority. 2019. 264 p. [in Ukrainian]. 